\title{
Paulina Daniluk
}

\section{PROBLEMATYKA OCHRONY WYNAGRODZENIA ZA PRACE - WYBRANE ASPEKTY}

\section{UWAGI WSTĘPNE}

Celem pracy jest przeprowadzenie analizy aktualnego stanu prawnego w przedmiocie ochrony wynagrodzenia za pracę, która pozwoli odpowiedzieć na pytanie, czy przepisy de lege lata regulują tę kwestię w sposób kompleksowy. $Z$ uwagi na obszerność tej problematyki, niniejsze opracowanie zostanie ograniczone do rozdziału „Ochrona wynagrodzenia za pracę”, obejmującego art. 84-91 k.p.. Wybór ten jest podyktowany tym, że regularne i terminowe otrzymywanie wynagrodzenia $\mathrm{w}$ umówionej wysokości i formie, a kwestie te są przedmiotem regulacji tych artykułów, czyni zadość jego alimentacyjnej i bodźcowej funkcji. Punktem wyjścia będzie wyjaśnienie terminów „wynagrodzenie za pracę” oraz „ochrona wynagrodzenia za pracę”. Kolejna część artykułu poświęcona będzie pierwszej regule ochronnej, wynikającej z art. 84 k.p., ograniczającej swobodę pracownika $\mathrm{w}$ dysponowaniu prawem do należnego mu wynagrodzenia. Następnie omówione zostaną zasady rządzące wypłatą wynagrodzenia, dotyczące przede wszystkim terminu i formy wypłaty. Artykuł zamyka prezentacja rozległej problematyki potrąceń i odliczeń $z$ wynagrodzenia za pracę, co jest głównym - prawnie dopuszczalnym - sposobem zmniejszenia wynagrodzenia pracownika oraz wnioski de lege ferenda.

Wobec braku definicji terminu „wynagrodzenie za pracę” w k.p. próby jego wyjaśnienia podejmowane były w orzecznictwie sądowym. Według najczęściej prezentowanego poglądu, wynagrodzenie za pracę jest obowiązkowym, wypłacanym periodycznie, świadczeniem ze stosunku pracy o charakterze przysparzająco-majątkowym, należnym pracownikowi od pracodawcy za wykonaną pracę, w wysokości odpowiedniej do jej rodzaju, ilości i jakości ${ }^{1}$. Jest ono świadczeniem niejednorodnym, złożonym $\mathrm{z}$ elementów obligatoryjnych i dodatkowych, sta-

\footnotetext{
${ }^{1}$ Wyrok SN z dnia 14 października 1997r., I PKN 319/97, Lex nr 33044.
} 
łych i ruchomych. Termin wynagrodzenie za pracę stanowi określenie zbiorcze dla ogółu składników wynagrodzenia.

W literaturze przedmiotu termin techniczno-prawny „ochrona wynagrodzenia za pracę" obejmuje ogół gwarancji prawnych - materialnoprawnych i proceduralnych - otrzymywania przez pracownika godziwej zapłaty za świadczoną pracę w określonym terminie i bez dokonywania potrąceń innych niż wyraźnie przewidziane przez przepisy prawa ${ }^{2}$, a także środki nadzoru i kontroli nad przestrzeganiem przepisów dotyczących wynagrodzenia pracowniczego oraz ochronę wynagrodzenia $\mathrm{w}$ postępowaniu upadłościowym ${ }^{3}$. Celem przepisów dotyczących ochrony wynagrodzenia jest więc zabezpieczenie pracownika przed nieterminową wypłatą oraz bezprawnym obniżeniem czy utratą zarobku. Uprzywilejowanie tego świadczenia wynika przede wszystkim z jego alimentacyjnego charakteru, który przejawia się w tym, że jego celem podstawowym jest zaspokojenie potrzeb finansowych pracownika oraz jego rodziny.

\section{Niezbywalność Prawa Do Wynagrodzenia}

Art. 84 k.p. konstytuuje zakaz zrzekania się przez pracownika prawa do wynagrodzenia oraz przenoszenia tego prawa na inną osobę. Uzasadnieniem dla wprowadzenia ograniczeń $\mathrm{w}$ dysponowaniu prawem do wynagrodzenia przez samego pracownika jest jego słabsza pozycja względem pracodawcy, który mógłby wpłynąć na dokonanie przez pracownika niekorzystnych rozporządzeń swoim wynagrodzeniem, oraz konieczność regularnego dostarczania pracownikowi środków niezbędnych do utrzymania jego i jego rodziny".

Na gruncie art. 84 k.p. zrzeczenie się prawa do wynagrodzenia jest pojmowane bardzo szeroko. „Obejmuje swoją treścią wszelkie czynności (oświadczenia woli) pracownika, niezależnie od nadanej im nazwy, zmierzające - bezpośrednio

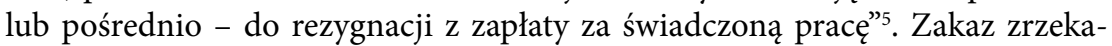
nia się prawa do wynagrodzenia ma charakter bezwzględny ${ }^{6}$ oraz powszechny ${ }^{7}$, a swoim zakresem obejmuje zarówno wynagrodzenie przyszłe, jak i wynagro-

${ }^{2}$ J. Skoczyński, Ochrona wynagrodzenia za pracę, PiZS 1997, nr 3, s. 17.

${ }^{3}$ J. Skoczyński, Prawna ochrona wynagrodzenia za prace, Warszawa 1995, s. 66-71, 80-91.

${ }^{4}$ T. Justyński, Zrzeczenie się odsetek za opóźnienie w wypłacie wynagrodzenia, „Praca i Zabezpieczenie Społeczne" 1995, nr 6, s. 58.

${ }^{5}$ Wyrok Sądu Najwyższego z dnia 17 lutego 2005r., II PK 235/04, Lex nr 155193.

${ }^{6}$ E. Suknarowska-Drzewiecka, Ochrona wynagrodzenia za prace - poradnik dla pracodawcy i pracownika, Warszawa 2008, s. 31-33.

${ }^{7}$ K. Wróblewska, Ochrona wynagrodzenia $w$ świetle orzecznictwa Sądu Najwyższego, PiZS 1999, nr 2, s. 37. 
dzenie należne ${ }^{8}$. „Zakaz ten (...) obejmuje zrzeczenie się prawa do wynagrodzenia za pracę w drodze wszelkich oświadczeń woli pracownika, także w drodze ugody sądowej" ${ }^{\prime \prime}$. Według stanowiska prezentowanego przez niektórych przedstawicieli doktryny, pośrednie zrzeczenie się prawa do części należnego wynagrodzenia jest dopuszczalne w postępowaniu upadłościowym prowadzonym z możliwością zawarcia układu. Jeżeli pracownik ma interes w przystąpieniu do układu, może wyrazić zgodę na objęcie tym układem jego należności ze stosunku pracy ${ }^{10}$.

Ograniczenie w dysponowaniu prawem do wynagrodzenia wyrażone w art. 84 k.p. obejmuje także zakaz przenoszenia tego prawa na inną osobę. Dotyczy to przelewu wierzytelności (art. 509 k.c.), w postaci pracowniczego prawa do wynagrodzenia, na rzecz osoby trzeciej. Zabronione jest również wystawienie weksla pod przyszłe wynagrodzenie czy ustanowienie zastawu na wynagrodzeniu ${ }^{11}$.

\section{Zasady Wyplaty Wynagrodzenia Za Prace}

„Prawidłowa wypłata wynagrodzenia” to pojęcie obejmujące wiele szczegółowych obowiązków spoczywających na pracodawcy i określające sposób właściwego wykonania zobowiązania. W jego zakres wchodzi: terminowość wypłaty, odpowiednia wysokość, forma i miejsce wypłaty wynagrodzenia oraz wypłata na rzecz osoby uprawnionej.

$\mathrm{Z}$ terminową wypłatą mamy do czynienia wówczas, gdy pracodawca wypłaca pracownikowi wynagrodzenie w pełnej wysokości w dniu, w którym jest do tego zobowiązany. Zgodnie z art. $86 \$ 1$ k.p., pracodawca jest obowiązany wypłacać wynagrodzenie w miejscu, terminie i czasie określonych w regulaminie pracy lub w innych przepisach prawa pracy. Niezależnie od ustaleń podjętych u konkretnego pracodawcy, termin i częstotliwość wypłaty powinny odpowiadać następującym warunkom ${ }^{12}$ :

${ }^{8}$ K. Powierza, Ochrona wynagrodzenia za prace, „Jurysta” 2006, nr 5, s. 13.

${ }^{9}$ Wyrok Sądu Najwyższego z dnia 3 lutego 2006r., II PK 161/05, Lex nr 227849; inaczej: E. Maniewska, [w:] Kodeks Pracy. Komentarz Lex, tom I, red. K. Jaśkowski, Warszawa 2012, s. 34 - Autorka jest zdania, że taka wykładnia prawa jest w niektórych sytuacjach, zwłaszcza jeśli chodzi o ugodę sądową lub ugodę zawartą przed mediatorem, sprzeczna ze słusznym interesem pracownika. Taki bezwzględny zakaz rezygnacji z uprawnień płacowych stawia pracownika na przegranej pozycji negocjacyjnej, w sytuacji gdy pewne ustępstwo z jego strony mogłoby zaowocować większą korzyścią.

${ }^{10} \mathrm{~K}$. Jaśkowski, Potrącenia $z$ wynagrodzenia za pracę wypłaconego z góry, „Prawo Pracy”, 1995, nr 7, s. 343.

${ }^{11}$ E. Suknarowska-Drzewiecka, op.cit., s. 31-32; M. Gersdorf, et al., op. cit., s. 525.

${ }^{12}$ L. Florek, Kodeks Pracy. Komentarz, Warszawa 2012, s. 486-490. 
1. dzień wypłaty powinien być stały i z góry ustalony - następuje to bądź przez wskazanie konkretnego dnia kalendarzowego, bądź przez określenie dnia tygodnia w każdym miesiącu;

2. wynagrodzenie należy wypłacać minimum raz w miesiącu - celem tej regulacji jest zapewnienie pracownikowi stałej, miesięcznej częstotliwości otrzymywania wypłaty. $Z$ tego względu pod pojęciem "miesiąca” należy rozumieć miesiąc obrachunkowy, który nie musi pokrywać się z miesiącem kalendarzowym $^{13}$;

3. jeżeli dzień wypłaty przypada na dzień wolny od pracy, wypłata wynagrodzenia następuje w dniu poprzednim - pod pojęciem „dni wolnych” należy rozumieć dni ustawowo wolne od pracy, dni wolne od pracy ustalone u konkretnego pracodawcy i dni wolne w rozumieniu przepisów o czasie pracy;

4. co do zasady, wynagrodzenie płatne raz w miesiącu wypłaca się z dołu - wynika to z zasady wynagradzania za pracę wykonaną, co jednak nie oznacza, że strony nie mogą postanowić w umowie o pracę, że wynagrodzenie będzie wypłacane z góry;

5. wynagrodzenie należy wypłacać niezwłocznie po ustaleniu jego wysokości, nie później niż w ciągu pierwszych 10 dni następnego miesiąca kalendarzowego - przesunięcie wypłaty o kilka dni kolejnego miesiąca jest dopuszczalne tylko wtedy, gdy wysokość wynagrodzenia zależy od ustalenia rezultatu pracy. Jeżeli obliczenie wysokości wynagrodzenia nie nasuwa żadnych trudności, należy je wypłacić niezwłocznie, tzn. na koniec miesiąca ${ }^{14}$;

6. składniki wynagrodzenia przysługujące za okresy dłuższe niż miesiąc wypłaca się z dołu, w terminach wskazanych w odrębnych przepisach.

Termin spełnienia świadczenia jest zachowany, gdy pracownik może dysponować swoim wynagrodzeniem. Toteż jeśli wypłata następuje $\mathrm{w}$ formie przelewu na konto bankowe, dniem spełnienia świadczenia jest dzień uznania rachunku bankowego, a nie dzień, $\mathrm{w}$ którym zostało złożone polecenie przelewu ${ }^{15}$.

Regułę dotyczącą ustalania wysokości wynagrodzenia określa art. $78 \$ 1$ k.p., który stanowi, że wynagrodzenie za pracę powinno być tak ustalone, aby odpowiadało w szczególności rodzajowi wykonywanej pracy i kwalifikacjom wymaganym przy jej wykonywaniu, oraz uwzględniało ilość i jakość świadczo-

${ }^{13}$ inaczej K. Rączka, [w:] Kodeks Pracy. Komentarz, red. M. Gersdorf, et al., Warszawa 2011, s. 526 - Według autora chodzi w tym wypadku o miesiąc kalendarzowy. Swoje stanowisko argumentuje brzmieniem końcowej części art. $85 \$ 1$ k.p. ("pierwszych 10 dni następnego miesiąca kalendarzowego") oraz funkcją alimentacyjną wynagrodzenia, bowiem podstawowe rachunki (np. za prąd) płatne są w odstępach miesięcy kalendarzowych.

${ }^{14}$ J. Skoczyński, Ochrona..., op.cit., s. 20.

${ }^{15}$ Uchwała SN z dnia 4 stycznia 1995r., III CZP 164/94, Lex nr 4159. 
nej pracy. Wynagrodzenie powinno być określone w umowie o pracę w sposób dokładny i nie budzący wątpliwości co do zasad jego wypłaty ustalonych przez strony, oraz powinno odpowiadać rodzajowi pracy (art. $29 \$ 1$ pkt 3 k.p.). Pracodawca musi wypłacać pracownikowi wynagrodzenie należne, tj. nie wyższe, ani nie niższe niż wynikające $\mathrm{z}$ umowy. Warunkiem umożliwiającym wypłacenie świadczenia w odpowiedniej wysokości jest bezbłędne ustalenie kwoty wynagrodzenia należnego pracownikowi. Na żądanie pracownika pracodawca ma obowiązek udostępnić mu do wglądu dokumenty, na podstawie których obliczono jego wynagrodzenie (art. $85 \$ 5$ k.p.). W ten sposób pracownik ma możliwość skontrolowania poprawności obliczania wysokości należnego mu wynagrodzenia i jego poszczególnych składników oraz zgodności przyjętej metody obliczeń z przepisami ${ }^{16}$.

Wynagrodzenie za pracę może być wypłacane w formie pieniężnej lub niepieniężnej. Wykonanie przez pracodawcę zobowiązania pieniężnego następuje przez zapłatę sumy nominalnej (art. $358^{1} \$ 1$ k.c.). Obecnie nie ma w Polsce zasady walutowości. Regulacja ta zezwala, by wynagrodzenie było wyrażone wprost $\mathrm{w}$ walucie obcej oraz upoważnia pracodawcę, jeżeli wynagrodzenie jest wyrażone w walucie obcej, do wyboru pomiędzy spełnieniem świadczenia w walucie obcej lub w złotych. Wykonanie zobowiązania pieniężnego może nastąpić w drodze zapłaty gotówkowej bądź w trybie rozliczeń bezgotówkowych ${ }^{17}$. Wypłata wynagrodzenia nie może nastąpić $\mathrm{w}$ formie pieniężnych papierów wartościowych, nawet jeżeli pracownik wyrazi zgodę na taki sposób zapłaty ${ }^{18}$.

Osobami uprawnionym do odbioru wynagrodzenia - poza samym pracownikiem - są: przedstawiciele ustawowi, osoby umocowane przez pracownika, osoby upoważnione z urzędu, oraz osoby mające własny tytuł prawny ${ }^{19}$.

Zgodnie z art. $86 \$ 3$ k.p., obowiązek wypłacenia wynagrodzenia może być spełniony w inny sposób niż do rąk pracownika, jeżeli tak stanowi układ zbiorowy pracy lub pracownik uprzednio wyrazi na to zgodę na piśmie. Oświadczenie, w którym pracownik wyraża zgodę na wypłatę wynagrodzenia w inny sposób niż do jego rąk, pracodawca powinien przechowywać w dokumentacji pracowniczej, ponieważ to na nim spoczywa ciężar dowodu co do poprawności wypłaty wynagrodzenia ${ }^{20}$.

${ }^{16}$ H. Rajczuk, Ochrona wynagrodzenia za pracę. Poradnik dla pracodawców $i$ pracowników, Wrocław 2003, s.10.

${ }^{17}$ Uchwała SN z dnia 4 stycznia 1995r., III CZP 164/94, Lex nr 4159.

18 Przyjęcie przez pracownika papierów wartościowych nie zwalnia pracodawcy $\mathrm{z}$ obowiązku wypłaty wynagrodzenia. Jednakże zobowiązanie to wygasa w zakresie, w jakim pracownik zrealizował papier wartościowy - J. Skoczyński, Prawna ochrona wynagrodzenia za pracę, Warszawa 2000, s. 61.

${ }^{19}$ J. Skoczyński, Prawna..., op. cit., s. 70.

${ }^{20}$ K. Spelak, Ochrona wynagrodzenia za prace, ,Jurysta” 2006, nr 1, s. 22. 
W myśl art. $86 \$ 2$ k.p., wypłaty wynagrodzenia dokonuje się w formie pieniężnej. Częściowe spełnienie wynagrodzenia w innej formie niż pieniężna (najczęściej w postaci tzw. deputatów) jest dopuszczalne tylko wówczas, gdy przewidują to ustawowe przepisy prawa pracy lub układ zbiorowy pracy. Wynika z tego, że nie można ustalić niepieniężnej formy wynagrodzenia za pracę $\mathrm{w}$ umowie o pracę czy w regulaminie wynagradzania.

\section{Potrącenia i Odliczenia z Wynagrodzenia za Pracę}

Potrącenie w rozumieniu k.p. należy rozumieć jako prawnie dopuszczalną oraz nakazaną prawem lub dozwoloną przez pracownika czynność polegającą na zmniejszeniu wysokości należnego mu wynagrodzenia, w ustawowo zakreślonych granicach ${ }^{21}$. Jest to ,jednostronne zmniejszenie przez pracodawcę wynagrodzenia o określone należności samego pracodawcy i osób trzecich"22. K.p. przewiduje możliwość zmniejszenia wynagrodzenia pracownika w drodze potrąceń ustawowych (dokonywanych na podstawie tytułu wykonawczego, niezależnie od woli pracownika) oraz dobrowolnych (dokonywanych za zgodą lub na wniosek pracownika).

Potrąceniu $\mathrm{z}$ wynagrodzenia za pracę bez zgody pracownika podlegają tylko należności wymienione enumeratywnie w art. $87 \$ 1$ k.p. Są to, z zachowaniem wskazanej kolejności: sumy egzekwowane na mocy tytułów wykonawczych na zaspokojenie bieżących i zaległych świadczeń alimentacyjnych, sumy egzekwowane na mocy tytułów wykonawczych na pokrycie należności innych niż świadczenia alimentacyjne, zaliczki pieniężne udzielone pracownikowi oraz kary pieniężne przewidziane w art. 108 k.p.

Potrącanie sum egzekwowanych na mocy tytułów wykonawczych jest obowiązkiem pracodawcy wynikającym z przepisów o postępowaniu egzekucyjnym. W literaturze wielokrotnie podkreśla się uprzywilejowanie świadczeń alimentacyjnych, pod pojęciem których rozumie się alimenty, oraz renty mające charakter alimentów. Należności inne niż świadczenia alimentacyjne są kwotami wynikającymi z obowiązku zapłaty lub odszkodowania, które pracownik jest obowiązany wypłacić osobie trzeciej ${ }^{23}$. W kwestii potrąceń, w sprawach nieunormowanych w k.p., stosuje się odpowiednio przepisy k.p.c. i przepisy o egzekucji administracyjnej świadczeń pieniężnych.

${ }^{21} \mathrm{P}$. Wąż, Świadczenia związane ze stosunkiem pracy podlegające ochronie $z$ art $87-91 \mathrm{KP}$, „Monitor Prawa Pracy” 2008, nr 8, s. 408.

22 T. Liszcz, Prawo pracy, Warszawa 2011, s. 297

${ }^{23} \mathrm{http} / / /$ www.serwisprawa.pl/artykuly,41,29,ochrona-wynagrodzenia-za-prace, 10.03 . $2014 \mathrm{r}$. 
Kolejnymi należnościami podlegającymi na mocy art. $87 \$ 1$ k.p. potrąceniu $\mathrm{z}$ wynagrodzenia za pracę są zaliczki pieniężne. Przyjmuje się, że zaliczka pieniężna w rozumieniu art. 87 k.p. to „wypłacona pracownikowi przez pracodawcę do rozliczenia stosowna kwota pieniężna na pokrycie obciążających pracodawcę wydatków, które ma uregulować lub ponieść pracownik w związku z wykonywaniem otrzymanego polecenia służbowego" ${ }^{24}$. Zaliczkami pieniężnymi są np. kwoty wypłacone na zakup paliwa do służbowego samochodu, pokrycie podróży służbowej, zakup materiałów i surowców niezbędnych do wykonywania pracy $^{25}$. Potrącenie $\mathrm{z}$ wynagrodzenia zaliczki pieniężnej jest typowym przejawem potrącenia właściwego (art. 498 i nast. k.c.) i może być dokonane dopiero, gdy bezskutecznie upłynął termin jej rozliczenia ${ }^{26}$.

Następną należnością, jaką można potrącić z wynagrodzenia za pracę, jest kara pieniężna nakładana $\mathrm{w}$ sytuacjach enumeratywnie wymienionych w art. $108 \$ 2$ k.p.. Potrącenie kary pieniężnej ma charakter bardziej zbliżony do pobrania (pracodawca pełni rolę ,inkasenta”), ponieważ nie występuje $\mathrm{w}$ tym przypadku element zaspokojenia roszczeń wierzyciela. Pracodawca nie może swobodnie dysponować środkami z kar pieniężnych, lecz musi je przeznaczyć na poprawę warunków bezpieczeństwa i higieny pracy. Kara pieniężna może być potrącona $\mathrm{z}$ wynagrodzenia nawet przed uprawomocnieniem się - stosownie do treści art. $112 \$ 3$ k.p., który stanowi, że w razie uwzględnienia sprzeciwu wobec zastosowanej kary pieniężnej lub uchylenia tej kary przez sąd pracy, pracodawca jest obowiązany zwrócić pracownikowi równowartość kwoty tej kary ${ }^{27}$.

Przy dokonywaniu potrąceń $z$ wynagrodzenia za pracę prawo przewiduje ograniczenia $^{28}: 1$ ) formalne - wymóg przeprowadzenia postępowania egzekucyjnego przed dokonaniem potrącenia; 2) przedmiotowe - wskazanie z czego można dokonać potrąceń, określenie ich rodzaju i kolejności; 3) podmiotowe - niemożliwości przeprowadzenia egzekucji przez polskie organy egzekucyjne 2002, s. 149.

${ }^{24}$ M. Piankowski, Ochrona pracowniczych świadczeń majątkowych, Bydgoszcz-Gdańsk

${ }^{25} \mathrm{~W}$ rozumieniu tego przepisu zaliczką pieniężną nie jest część wynagrodzenia, jaką pracownik otrzymuje na poczet wynagrodzenia przyszłego przed umówionym terminem płatności - wyrok SN z dnia 24 lipca 2011 r., I PKN 552/00, Lex nr 78461.

${ }^{26}$ K. Rymkiewicz, Potracenie $z$ wynagrodzenia za prace, [w:] Studia z zakresu prawa pracy i polityki społecznej, red. A. Świątkowski, Kraków 2011, s. 82.

${ }^{27}$ inaczej: J. Wratny et. al., op. cit., s. 117 - Kary, aby spełniały swoje zadanie, powinny być potrącane z wynagrodzenia przysługującego za okres rozliczeniowy, w którym uprawomocniła się decyzja o jej wymierzeniu.

${ }^{28}$ R. Golat, Ograniczenia potrąceń z wynagrodzeń, „Służba Pracownicza” 2013, nr 2, s. $10-11$. 
przeciwko niektórym podmiotom; 4) ilościowe - ograniczenia wysokości dopuszczalnych potrąceń.

Podstawą do dokonywania potrąceń jest kwota netto, czyli kwota przeznaczona ostatecznie do wypłaty. Stanowi to dodatkową gwarancję otrzymania przez pracownika środków niezbędnych do utrzymania. Potrąceń należności $\mathrm{z}$ wynagrodzenia pracownika w miesiącu, w którym są wypłacane składniki wynagrodzenia za okresy dłuższe niż 1 miesiąc, dokonuje się od łącznej kwoty wynagrodzenia uwzględniającej te składniki wynagrodzenia.

Wskazanie granic dopuszczalnych potrąceń następuje przez ułamkowe i kwotowe określenie kwoty wolnej od potrąceń.

Art. $87 \$ 3$ i 4 k.p. wyznaczają ułamkowe, górne granice dopuszczalności potrąceń z wynagrodzenia pracownika: 1) w razie egzekucji świadczeń alimentacyjnych oraz w razie zbiegu egzekucji świadczeń alimentacyjnych z egzekucją innych należności lub potrącaniem zaliczek pieniężnych - do trzech piątych wynagrodzenia; 2) w razie egzekucji innych należności niż świadczenia alimentacyjne, potrącania zaliczek pieniężnych lub przy dokonywaniu tych potrąceń łącznie - do połowy wynagrodzenia. Na zaspokojenie świadczeń alimentacyjnych podlegają, w myśl art. $87 \$ 5$ k.p., egzekucji do pełnej wysokości: nagroda z zakładowego funduszu nagród, dodatkowe wynagrodzenie roczne, należności przysługujące pracownikom z tytułu udziału w zysku lub w nadwyżce bilansowej.

Inne reguły obowiązują przy potrącaniu kar pieniężnych. Maksymalne granice kar pieniężnych są uregulowane osobno w art. 108 k.p. Wskazany przepis wiąże pracodawcę dwoma limitami: 1) kara pieniężna za jedno przekroczenie jak i za każdy dzień nie usprawiedliwionej nieobecności nie może być wyższa od jednodniowego wynagrodzenia pracownika; 2) łącznie kary pieniężne nie mogą przewyższać dziesiątej części wynagrodzenia przypadającego pracownikowi do wypłaty, po dokonaniu potrąceń sum egzekwowanych na podstawie tytułów wykonawczych oraz zaliczek pieniężnych. Uprzywilejowanie tych potrąceń polega na tym, że dokonuje się ich niezależnie od pozostałych potrąceń. Wynagrodzenie może zostać pomniejszone o karę pieniężną pomimo niezaspokojenia $\mathrm{w}$ całości innych należności korzystających z pierwszeństwa, o ile pozostanie odpowiednia kwota wolna od potrąceń.

Kolejną, tzw. dolną granicą potrąceń, jest kwota wolna od potrąceń. Pracodawca nie może zostawić pracownikowi do dyspozycji wynagrodzenia niższego niż wskazana kwota. Zgodnie $\mathrm{z}$ art. $87^{1} \$ 1$ k.p, wolna od potrąceń jest kwota wynagrodzenia za pracę $\mathrm{w}$ wysokości: minimalnego wynagrodzenia za pracę - przy potrącaniu sum egzekwowanych na mocy tytułów wykonawczych na pokrycie należności innych niż świadczenia alimentacyjne; 75\% minimalnego wynagrodzenia za pracę - przy potrącaniu zaliczek pieniężnych udzielonych 
pracownikowi; 90\% minimalnego wynagrodzenia za pracę - przy potrącaniu kar pieniężnych. Podkreślić należy, że przy dokonywaniu potrąceń na pokrycie świadczeń alimentacyjnych, pracownikowi nie została zagwarantowana kwota wynagrodzenia wolna od potrąceń.

Jeżeli pracownik jest zatrudniony w niepełnym wymiarze czasu pracy, kwota wolna od potrąceń ulega, zgodnie $\mathrm{z}$ art. $87^{1} \$ 2 \mathrm{k} . \mathrm{p}$, zmniejszeniu proporcjonalnie do wymiaru czasu pracy. Nie została przewidziana możliwość podwyższenia tych kwot $\mathrm{w}$ razie wykonywania pracy ponad normalny wymiar czasu pracy u jednego pracodawcy. Nie jest jasna kwestia sposobu liczenia kwoty wolnej od potrąceń w przypadku uzyskiwania dochodów z wielu źródeł w związku z zatrudnieniem danej osoby u kilku pracodawców. Według niektórych autorów, przy potrącaniu należności egzekwowanych na mocy tytułów wykonawczych wynagrodzenie pracownika zatrudnionego u kilku pracodawców podlega zsumowaniu w celu określenia kwoty wolej od potrąceń29 ${ }^{29}$ Stanowisko to jest pozostałością po nieobowiązującym już rozporządzeniu Rady Ministrów z dnia 6 grudnia 1977 r. w sprawie kwot wynagrodzenia za pracę wolnych od potrąceń z innych tytułów niż świadczenia alimentacyjne, które zawierało przepis o takiej treści. Z powodu nieprzejęcia tego uregulowania przez prawodawcę, należy opowiedzieć się za innym poglądem. Mianowicie, że dla pracownika zatrudnionego u kilku pracodawców kwoty wolne od potrąceń ustala się oddzielnie u każdego pracodawcy ${ }^{30}$.

Art. 88 k.p. daje wierzycielowi alimentacyjnemu prawo dochodzenia swoich roszczeń bez przeprowadzania postępowania egzekucyjnego pod warunkiem przedłożenia pracodawcy wniosku wraz z tytułem wykonawczym (art. $88 ₫ 2$ k.p.). Kolejną przesłanką, warunkującą możliwość pozyskania z wynagrodzenia za pracę kwot na zaspokojenie świadczeń alimentacyjnych w trybie bezegzekucyjnym, jest brak przeszkód określonych $w$ art. $88 \$ 1$ k.p.. Chodzi mianowicie o sytuacje, gdy: 1) świadczenia alimentacyjne mają być potrącane na rzecz kilku wierzycieli, a łączna suma, która może być potrącona, nie wystarcza na pełne pokrycie wszystkich należności alimentacyjnych; 2) wynagrodzenie za pracę zostało zajęte w trybie egzekucji sądowej lub administracyjnej.

Potrącenia dobrowolne dokonywane są po przeprowadzeniu potrąceń obowiązkowych. Art. $91 \$ 1$ k.p. stanowi, że należności inne niż wymienione $\mathrm{w}$ art. $87 \$ 1$ i 7 k.p. mogą być potrącane z wynagrodzenia pracownika tylko za

${ }^{29}$ A. Matusiak-Wojnicz, P. Wojnicz, Egzekucyjne i nieegzekucyjne potrącenia z wynagrodzeń, Wrocław 2012, s. 158 - Autorzy powołują się na brzmienie art. 835 k.p.c., zgodnie z którym jeżeli dłużnik uzyskuje dochody z kilku źródeł, podstawę obliczenia kwoty wolnej od potrąceń stanowi suma wszystkich dochodów.

${ }^{30}$ A. Śmigaj, Prawne możliwości dokonywania potrąceń $z$ wynagrodzenia pracownika - praktyczny przewodnik, „Monitor Prawa Pracy” 2010, nr 1, s. 24. 
jego zgodą wyrażoną na piśmie ${ }^{31}$. Pracownik powinien określić na piśmie kwotowo lub procentowo ( $\mathrm{z}$ uwzględnieniem granic $\mathrm{z}$ art. $91 \$ 2 \mathrm{k}$.p.) wysokość wynagrodzenia, do potrącania którego upoważnia pracodawcę. Zgoda może dotyczyć tylko należności istniejących w momencie jej wyrażania, przy czym bez znaczenia jest fakt, czy wierzytelność jest już wymagalna ${ }^{32}$. Pracownik nie ma możliwości wyrażenia zgody na potrącenie ewentualnych przyszłych długów ${ }^{33}$. Nieważna jest również zgoda na potrącenie $\mathrm{z}$ wynagrodzenia za pracę należności obciążających pracodawcę ${ }^{34}$, oraz zgoda na dokonanie potrąceń bez świadomości wielkości długu i istnienia przesłanek odpowiedzialności ${ }^{35}$. Można zatem stwierdzić, że zgoda pracownika na dokonanie potrąceń z wynagrodzenia za pracę jest skuteczna, gdy ma on świadomość wysokości należności, lub przynajmniej podstaw pozwalających na określenie tej wysokości ${ }^{36}$. Granice potrąceń dobrowolnych są unormowane w art. $91 \$ 2$ k.p. tylko przez wskazanie kwoty wolnej od potrąceń (nie została ustalona górna granica możliwości dokonywania potrąceń w tym trybie). Zgodnie z tym przepisem, pracownikowi należy pozostawić: kwotę minimalnego wynagrodzenia za pracę - przy potrącaniu należności na rzecz pracodawcy; lub $80 \%$ kwoty minimalnego wynagrodzenia za pracę - przy potrącaniu należności na rzecz innych niż pracodawca podmiotów.

$\mathrm{Z}$ wynagrodzenia za pracę odlicza się składki na ubezpieczenie społeczne, zaliczki na podatek dochodowy od osób fizycznych (art. $87 \$ 1$ k.p.) oraz kwoty wypłacone w poprzednim terminie płatności za okres nieobecności w pracy, za który pracownik nie zachowuje prawa do wynagrodzenia (art. $87 \$ 7$ k.p.). Odliczeń dokonuje się bez zgody pracownika ${ }^{37}$, w pełnej wysokości, niezależnie od kwoty nadpłaty ${ }^{38}$.

Przedstawiciele doktryny nie są zgodni co do kolejności dokonywania potrąceń i odliczeń $\mathrm{z}$ art. $87 \$ 7$ k.p. Zdecydowana większość, której pogląd podzielam, jest zdania, że odliczeniom należy przyznać pierwszeństwo przed potrąceniami ${ }^{39}$.

${ }^{31}$ Wyrok SN z dnia 1 października 1998r., I PKN 366/98, Lex nr 37722.

${ }^{32}$ J. Skoczyński, Ochrona..., op. cit., s. 22.

${ }^{33}$ E. Suknarowska-Drzewiecka, op. cit., s. 44.

${ }^{34}$ Wyrok SN z dnia 12 września 2000 r., I PKN 22/00, Lex nr 51749.

${ }^{35}$ Wyrok SN z dnia 5 maja 2004 r., I PK 529/03, „Prawo Pracy” 2004, nr 10, poz. 35.

${ }^{36}$ R. Sadlik, Zakres potrąceń i odliczeń z wynagrodzenia za pracę, „Prawo Pracy” 1999, nr 7, s. 18.

${ }^{37}$ Wyrok SN z dnia 11 października 1994 r., I PRN 81/94, Lex nr 11926.

${ }^{38}$ M. Gersdorf, glosa do wyroku Sądu Najwyższego z dnia 4 października 1994 r., I PRN 71/94, OSP, 1996, zeszyt 4, poz. 73.

${ }^{39}$ J. Skoczyński, Prawna..., op. cit., s. 74; A. Kosut, W. Perdeus, Egzekucja administracyjna $z$ wynagrodzenia za pracę [w:] System egzekucji administracyjnej, red. J. Niczyporuk, S. Fundowicz, J. Radwanowicz, Warszawa 2004, s. 322. 
Za stanowiskiem tym ma przemawiać sformułowanie użyte przez ustawodawcę $\mathrm{w}$ art. $87 \$ 7$ k.p., zgodnie z którym odliczeń dokonuje się „w pełnej wysokości”. Według mnie nie jest to racjonalny argument ze względu na brak przewidzianych w Kodeksie ograniczeń, w postaci „kwoty wolej od odliczeń” lub dopuszczalnej górnej granicy odliczeń, które mogłyby uniemożliwić pracodawcy otrzymanie pełnego zwrotu nienależnie wypłaconych kwot. Według innego poglądu, pracodawca może dokonać odliczeń na podstawie art. $87 \$ 7$ k.p. dopiero $\mathrm{z}$ kwoty pozostałej po potrąceniu należności wymienionych $\mathrm{w}$ art. $87 \$ 1$ pkt 1-4 k.p. ${ }^{40}$. Trudno zgodzić się z tym stanowiskiem $\mathrm{z}$ uwagi na fakt, że prowadziłoby to do absurdalnej sytuacji, w której dokonywano by potrąceń ze środków, które de facto nie są wynagrodzeniem za pracę ani żadna inną należnością pracownika związaną za stosunkiem pracy.

\section{UWAgI Końcowe}

Analiza przepisów kodeksowych pozwala na stwierdzenie, że regulują one ochronę wynagrodzenia za pracę w sposób kompleksowy i prawidłowy. Zwłaszcza przepisy dotyczące zasad wypłaty wynagrodzenia, oraz kolejności i granic dopuszczalnych potrąceń i odliczeń z wynagrodzenia i trybów ich dokonywania zasługują moim zdaniem na wysoką ocenę.

Poważnym problemem jest jednak brak definicji legalnej „wynagrodzenia za pracę", która pozwoliłaby na precyzyjne określenie zakresu ochrony. Jej absencja powoduje szereg wątpliwości, które orzecznictwo stara się usuwać, zmierzając tym samym w kierunku rozszerzania granic ochronnych k.p., co z perspektywy pracownika jest jak najbardziej pożądane. Niemniej, brak tej definicji jest wadą legislacyjną wpływającą niekorzystnie na inne regulacje.

Ponadto art. 84 k.p., wprowadzający kategoryczny zakaz zrzekania się prawa do wynagrodzenia wydaje się zbyt rygorystyczny. W literaturze również zostało zauważone, że w tej kwestii pracownik ma „związane ręce” i nawet przy perspektywie większej korzyści, jaką mógłby osiągnąć, idąc na pewne ustępstwa wobec pracodawcy, nie ma mu nic do zaoferowania. Moim zdaniem, należy rozważyć wprowadzenie bardzo ograniczonej możliwości zrzeczenia się przez pracownika wynagrodzenia w drodze ugody zawieranej z pracodawcą.

Kwestią odnoszącą się bezpośrednio do alimentacyjnego charakteru wynagrodzenia, a nieporuszoną $\mathrm{w}$ artykule, pozostaje problem godziwości tego

${ }^{40}$ K. Jaśkowski, op.cit., s. 19 - Autor uzasadnia swoje stanowisko uprzywilejowanym charakterem należności wymienionych w art. $87 \$ 1$ oraz systematyką przepisów, tj. umieszczeniem art. $87 \$ 7$ na końcowym miejscu wśród przepisów regulujących możliwość dokonania potrąceń $\mathrm{z}$ wynagrodzenia pracownika bez jego zgody. 
świadczenia. Stosownie do postanowień art. 4 Europejskiej Karty Społecznej ${ }^{41}$, zarobek uzyskiwany przez pracownika powinien być godziwy i zapewniać zadowalające warunki życia dla pracowników i ich rodzin. Komitet Niezależnych Ekspertów Rady Europy dokonując wykładni tego przepisu określił „próg godziwości” na poziomie $60 \%$ wynagrodzenia przeciętnego. Konstytucja RP w art. 65 ust. 4 stanowi, że minimalną wysokość wynagrodzenia za pracę lub sposób ustalania tej wysokości określa ustawa. W Polsce relacja wynagrodzenia minimalnego do wynagrodzenia przeciętnego kształtuje się na poziomie $45 \%$ i tym samym wynagrodzenie minimalne nie spełnia wymogu godziwości.

\section{PROBLEMATIC ASPECTS OF PROTECTION OF REMUNERATION FOR WORK - SELECTED ISSUES}

The subject of this article is the analysis of law as it stands regarding protection of remuneration for work regulated in the Labour Code. The starting point is to explain the meaning of a term "remuneration for work" which is not defined in the statute. The second part deals with the protective regulation concerning the prohibition against renouncing the right to remuneration. In the another part of this article the author depicts the issue of rules of payment of remuneration, especially forms, procedures and day of payment. The last subsection covers the aspect of deductions from remuneration. In closing remarks, the author presents de lege ferenda conclusions concerning future legislative improvements.

${ }^{41}$ Europejska Karta Społeczna sporządzona w Turynie dnia 18 października 1961 r., Dz. U. z 1999 r., nr 8, poz. 67 - Art. 4. nie został ratyfikowany przez Polskę. 